\title{
Holocene climate variability and
} vegetation dynamics inferred from the
(11 700 cal. yr BP) Laguna Rabadilla de
Vaca sediment record, southeastern
Ecuadorian Andes

\author{
Holger Niemann, ${ }^{1 *}$ Torsten Haberzettl ${ }^{2}$ and Hermann Behling ${ }^{1}$
}

\author{
( ${ }^{1}$ Department of Palynology and Climate Dynamics, Albrecht-von-Haller-Institute for Plant Sciences, \\ University of Göttingen, Untere Karspüle 2, 37073 Göttingen, Germany; ${ }^{2}$ ISMER (Institut des Sciences \\ de la mer de Rimouski), University of Québec at Rimouski, 310 allée des Ursulines, Rimouski, Québec, \\ Canada)
}

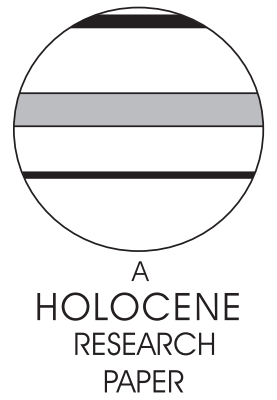

\section{Introduction}

The Ecuadorian Andes harbour the most species-rich ecosystems on Earth (Barthlott et al., 2005). Despite its high biodiversity huge areas have been strongly affected by human activity (eg, industrial deforestation) during the last decades. Natural vegetation regeneration and sustainable management, as well as conservation of less degraded areas is urgently needed. To study the highly diverse mountain forest and paramo ecosystems in southeastern Ecuador, extended research has been carried out in the framework of the

\footnotetext{
*Author for correspondence (e-mail: holnie@web.de)
}

'Deutsche Forschungsgemeinschaft' (DFG) research group 'Tropical Mountain Ecosystems' focusing on Podocarpus National Park (Beck et al., 2008). Currently (2007-2010) more than 25 different research groups are working in this area. Palaeoecological work analysing more than ten different lake, peat and soil cores in the Podocarpus National Park region started in 2005. Palaeoecological information is needed to understand the natural composition and dynamics of modern ecosystems for proper management and conservation.

Among the few palaeoenvironmental records are available from the southeastern Ecuadorian Andes are those from the El Tiro-Pass (2810 $\mathrm{m}), c .30 \mathrm{~km}$ north of the core site (Niemann and Behling, 2008a) and from Laguna Cocha Caranga ( $2710 \mathrm{~m}), c .25 \mathrm{~km}$ north of the core site (Niemann and Behling, 2008b). Neighbouring regions in South 


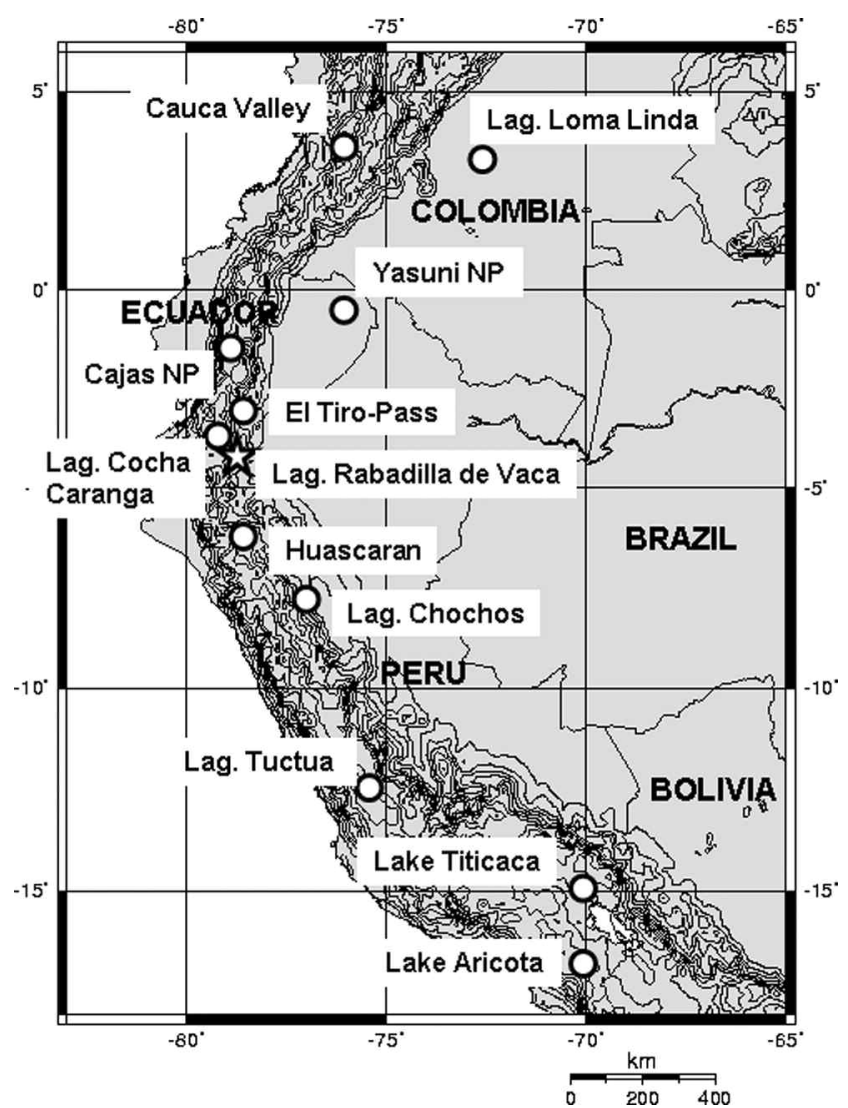

Figure 1 Map of central northwestern tropical South America, showing Laguna Rabadilla de Vaca (star) and other locations discussed in the text (circles)

America offer archives, for example from the Colombian interAndean Cauca Valley (1020 m) (Berrio et al., 2002), from Laguna Loma Linda $(310 \mathrm{~m})$, located in the transition zone between the savannah of the Llanos Orientales and the Amazon rainforest in Colombia (Behling and Hooghiemstra, 2000), from the Yasuni National Park $(220 \mathrm{~m})$ in the Ecuadorian Amazonia (Weng et al., 2002), from Laguna Chochos (3285 m) in the eastern Peruvian Andes (Bush et al., 2005), from Laguna Tuctua in the central Peruvian Andes (4000 m) (Hansen et al., 1994), from Lake Titicaca $(3810 \mathrm{~m})$ in the central Peruvian Andes (D'Agostino et al., 2002; Paduano et al., 2003), from Lake Aricota at $2800 \mathrm{~m}$ in the central Peruvian Andes (Placzek and Quade, 2001) and from Huascaran (c. $6050 \mathrm{~m}$ ) in the central Peruvian Andes (Thompson et al., 1995). Locations of greater interest for this study are shown in Figure 1.

In this study we seek to address the following main questions: (1) how did climate and vegetation develop at Laguna Rabadilla de Vaca during the Holocene period in comparison with preceding studies from the Podocarpus National Park region; and (2) is there an interregional coherence with studies from outside Ecuador?

\section{Site description}

\section{Location}

Laguna Rabadilla de Vaca (04¹5'19.7"S, 07906'43.7”W, $3312 \mathrm{~m})$ is located on the western slope of the eastern Cordillera (Cordillera Real) in the southeastern Ecuadorian Andes (Figure 1), about 10 $\mathrm{km}$ east of the small village of Vilcabamba $(1700 \mathrm{~m})$ and about 15 $\mathrm{km}$ south of Cajanuma (Podocarpus National Park entrance). Laguna Rabadilla de Vaca is part of the so called Lagunas de Compadre, a group of 15 lakes formed by glaciers, located east and west of the eastern Cordillera in the middle of the Podocarpus National Park.

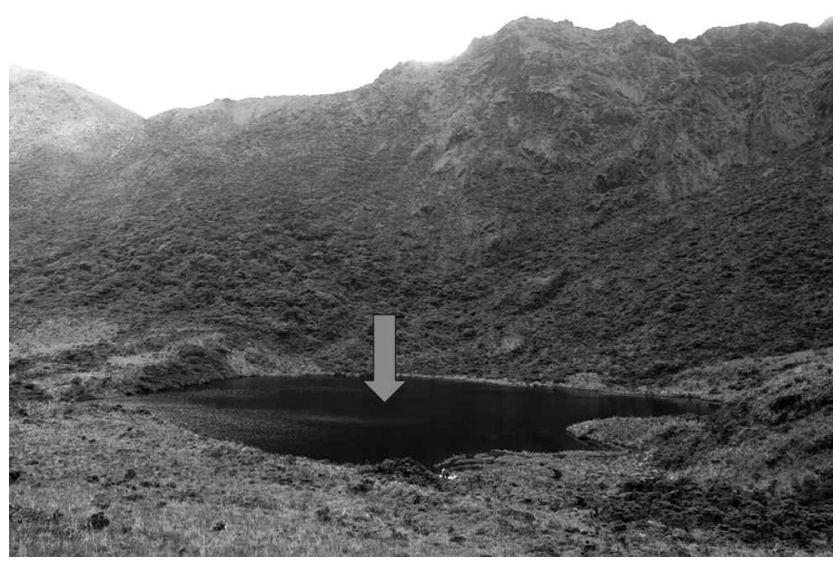

Figure 2 Photograph (from southwest) of Laguna Rabadilla de Vaca, with the east Andean divide in the background. The slopes are covered with shrub-paramo vegetation and the lake shore covered with herbparamo vegetation. The coring position is marked with an arrow

\section{Geomorphology and geology}

The Andes of southern Ecuador and northern Peru include the socalled Andean depression (Depression de Giron-Cuenca in Ecuador and Huancabamba in Peru). The highest peaks reach about $4000 \mathrm{~m}$ elevation; and there are no active volcanoes in the region (Richter and Moreira-Munoz, 2005).

Laguna Rabadilla de Vaca (Figure 2) is located toward the west, very close to the eastern Andean divide at the base of a cliff created by a large valley glacier originating on higher elevations of the divide. Slopes east of the lake shore reach $3600-3700 \mathrm{~m}$. To the west, the 6 ha in size and c. $5 \mathrm{~m}$ deep lake is dammed by a recessional moraine. The catchment of the westward-draining lake is about $2 \mathrm{~km}^{2}$.

The southern Cordillera Real is mainly built up by the 'Zamora series', consisting of Palaeozoic metamorphic rocks of widely varying metamorphic grade. Local bedrock is dominated by semipelites, quartzites and black phylites with some granitic intrusions (Litherland et al., 1994).

\section{Modern vegetation}

Laguna Rabadilla de Vaca is located in the paramo vegetation zone. Two different types of paramo ecosystems are identified for the Podocarpus National park region (Lozano et al., 2003). The herbparamo (Paramos herbaceos), located at c. $3200-3400 \mathrm{~m}$, is rich in Neurolepis nana, Calamagrostis macrophylla (Poaceae) and Niphogeton dissecta (Apiaceae). The herbs and shrubs grow from 0.2 $\mathrm{m}$ to $1 \mathrm{~m}$ in height. This paramo type is found along flat slopes and concave sections, as well as along ridges. This herb-paramo is dominant around Laguna Rabadilla de Vaca. The shrub-paramo (Paramos arbustivos bajos), located at c. 2900-3400 m, is rich in Weinmannia rollottii (Cunoniaceae), Oxalis spiralis (Oxaliaceae) and Ilex andicola (Aquifoliaceae). The shrubs and herbs grow from $0.5 \mathrm{~m}$ to $1.2 \mathrm{~m}$ in height. This paramo type is found mainly along steep slopes (Lozano et al., 2003), which is confirmed by the fact that the slopes above Laguna Rabadilla de Vaca are dominated by this paramo type.

At lower altitudes between $c .2800$ and $3100 \mathrm{~m}$, subparamo vegetation is present, characterized by Puya nitida (Bromeliaceae), Brachyotum rotundifolium (Melastomataceae) and Oritrophium peruvianum (Asteraceae). The shrubs and herbs mainly grow to 1 $\mathrm{m}$ in height; some individual shrub species can be $2-3 \mathrm{~m}$ tall (Lozano et al., 2003).

The modern treeline in northern and central Ecuador is at about $3400-3600 \mathrm{~m}$. At the El Tiro-Pass, $30 \mathrm{~km}$ north of the core site, the modern treeline is at $c$. $2800 \mathrm{~m}$, which is about $600-800 \mathrm{~m}$ lower. A shift of vegetation zones to lower elevation is probably a result of the so-called Andean depression (Bader, 2007). 
Table 1 AMS-radiocarbon dates and calibrated ages for the lake core from Laguna Rabadilla de Vaca

\begin{tabular}{|c|c|c|c|c|c|c|}
\hline Core name & Laboratory code & Dated material & Core depth & ${ }^{14} \mathrm{C}$ yr BP & Median calibrated age (cal. yr BP) & $2 \sigma$ age range (cal. yr BP) \\
\hline Lag. Rabadilla de Vaca & Erl-8896 & Bulk sample & $96 \mathrm{~cm}$ & $1887 \pm 38$ & 1770 & $1630-1875$ \\
\hline Lag. Rabadilla de Vaca & Erl-8895 & Bulk sample & $278 \mathrm{~cm}$ & $4603 \pm 45$ & 5170 & $4990-5445$ \\
\hline Lag. Rabadilla de Vaca & Erl-11032 & Bulk sample & $360 \mathrm{~cm}$ & $6822 \pm 88$ & 7620 & $7460-7790$ \\
\hline Lag. Rabadilla de Vaca & Erl-8375 & Bulk sample & $450 \mathrm{~cm}$ & $9262 \pm 81$ & 10380 & $10225-10555$ \\
\hline
\end{tabular}

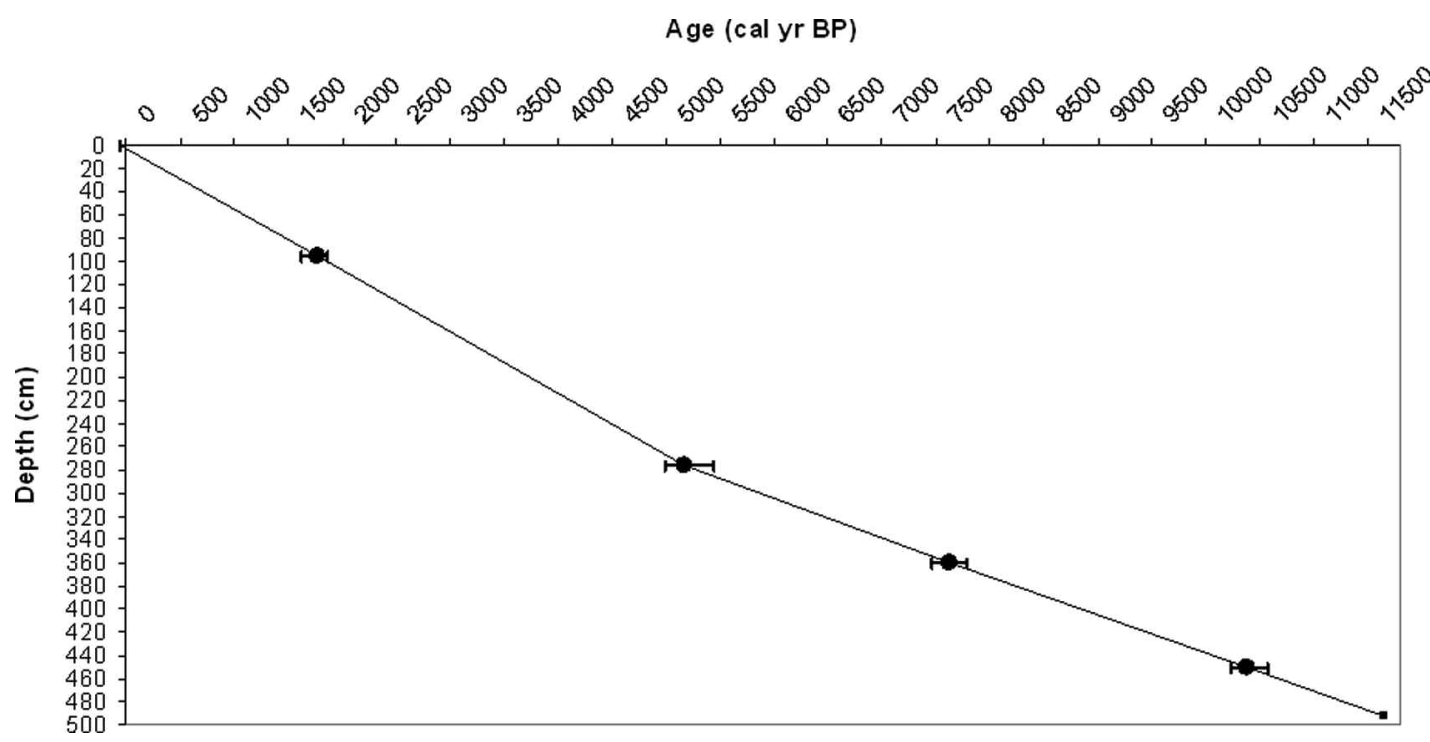

Figure 3 Age-depth model (cal. yr BP/core depth in cm) of Laguna Rabadilla de Vaca lake sediment core

Two different mountain rainforest ecosystems exist in the Podocarpus National Park region. The upper mountain rainforest, located between c. 2100 and $2750 \mathrm{~m}$, consists of low, monotypic formation, with only one tree stratum between 5 and $10 \mathrm{~m}$; rarely up to $15 \mathrm{~m}$. Characteristic trees include Purdiaea nutans (Cyrillaceae), Myrica pubescens (Myricaceae) and Myrsine andina (Myrsinaceae). The lower mountain rainforest is located between c. 1800 and $2150 \mathrm{~m}$ with an extremely diverse, two-storied tree stratum and is composed of numerous $20-35 \mathrm{~m}$ tall tree species. Characteristic species include Alzetea verticillata (Alzataceae), Graffenrieda miconioides (Melastomataceae) and Myrcianthes sp. (Myrtaceae); (Bussmann, 2001, 2005; Lozano et al., 2003).

\section{Climate}

The climate in the southeastern Ecuadorian Andes is influenced by warm moisture-laden air from the Amazon lowland, which collides with cold mountain air masses. This produces much of the rainfall in the eastern Andean mountains. The climate of the paramo is classified as humid tropical diurnal with cold nights and cool days. There is a dry season that lasts from December until March (Bosman et al., 1994). As part of the Andean depression, all summits in the southern Ecuadorian Andes are below the snowline.

The eastern Andean mountains form a division that separates the moist eastern slopes of the Andes from the dry inner-Andean basins (eg, the Loja- and Catamayo Basin). Between the eastern slopes of the eastern Cordillera and the dry valley of Catamayo, which are only $70 \mathrm{~km}$ apart, annual rainfall rates drop from over $4000 \mathrm{~mm}$ to $300 \mathrm{~mm}$ (Bendix et al., 2004).

Laguna Rabadilla de Vaca is located close to the eastern Andean divide and highly influenced by easterly trade winds (average annual speed $9.3 \mathrm{~m} / \mathrm{s}$ ) from the Amazon lowland. In the winter months (June-August), this trade wind system is very strong and stable, occasionally interrupted by westerly winds in the summer months (November-March). Annual precipitation at Cajanuma, located on the western slope $(3400 \mathrm{~m})$ is about 5700 $\mathrm{mm}$ and the average annual temperature is about $6.9^{\circ} \mathrm{C}(\mathrm{Emck}$, 2007).

\section{Material and methods}

A $492 \mathrm{~cm}$ long sediment core was recovered with a Livingstone piston-corer near the centre of the lake (c. $5 \mathrm{~m}$ water depth) from an inflatable rubber raft (Figure 2). Core sections of $1 \mathrm{~m}$ were recovered in tubes and stored under dark and cold $\left(+4^{\circ} \mathrm{C}\right)$ conditions before processing.

Four bulk subsamples (organic) were submitted for Accelerator Mass Spectrometer (AMS) radiocarbon dating (Table 1). Radiocarbon dates were performed at the University of Erlangen/Nürnberg, Germany. There is no carbonate bedrock in the catchment, which might contaminate the bulk samples. Radiocarbon ages were calibrated using Calib 5.0.2 (Stuiver and Reimer, 1993), performed with the Southern Hemisphere calibration curve (McCormac et al., 2004). Median ages of the $2 \sigma$ distribution were used for the age-depth model (Figure 3 ).

A total of 52 subsamples $\left(0.25 \mathrm{~cm}^{3}\right)$ were taken from the sediment core for palynological and charcoal analyses mainly at $10 \mathrm{~cm}$ $(5 \mathrm{~cm})$ intervals. All samples were processed with standard analytical methods (Faegri and Iverson, 1989). Exotic Lycopodium spores were added to each sample before treatment for calculation of pollen and charcoal concentration. Approximately 300 pollen grains were counted for each sample. The pollen sum includes tree, shrub and herb pollen and excludes spores. Pollen identification 
was based on the reference collection of $\mathrm{H}$. Behling, which includes about 3000 neotropical species, and on the literature (Hooghiemstra, 1984; Behling, 1993). A reference collection with about 300 species, collected during fieldwork and at the herbarium of the (ECSF) research station is also available.

The grouping of the identified pollen taxa into lower and upper mountain rainforest, subparamo and paramo has been carried out according to available data from the literature (Bussmann, 2001, 2005; Lozano et al., 2003; Homeier and Werner, 2005). Pollen and spore data are presented in pollen diagrams as percentages of the terrestrial pollen sum. Pollen concentration (grains $/ \mathrm{cm}^{3}$ ) and influx (grains $/ \mathrm{cm}^{2}$ per yr) were also calculated. Carbonized particles $(10-150 \mu \mathrm{m})$ were counted on pollen slides and presented as influx (particles $/ \mathrm{cm}^{2}$ per yr). Pollen diagrams were created with TILIA, TILIAGRAPH and CONISS (Grimm, 1987).

Non-destructive magnetic susceptibility $(\kappa)$ scanning was performed, on split cores with a Bartington MS2F point sensor at $1 \mathrm{~cm}$ resolution. An Avaatech XRF-scanner provided semi-quantitative analyses of $\mathrm{Al}, \mathrm{Si}, \mathrm{S}, \mathrm{K}, \mathrm{Ca}, \mathrm{Ti}, \mathrm{Mn}$ and $\mathrm{Fe}$ (Richter et al., 2006; Tjallingii et al., 2007) at $1 \mathrm{~cm}$ depth intervals (see Figure 6). Values are given in total counts (cnts).

\section{Results}

\section{Stratigraphy}

The $492 \mathrm{~cm}$ long lake sediment core from Laguna Rabadilla de Vaca consists of dark brown fine detrital mud (see Figure 5). The organic material is interrupted by three light brown $3-4 \mathrm{~cm}$ thick clay layers at 190, 280 and $295 \mathrm{~cm}$ sediment depth. The clay layers have sharp erosive bases.

\section{Chronology}

Four AMS radiocarbon dates (Table 1) provide the chronological control for the sediment core from Laguna Rabadilla de Vaca. The AMS date close to the base of the core $(450 \mathrm{~cm}$ core depth) indicates Holocene deposits. Extrapolation of the age-depth model shows an age of $11700 \mathrm{cal}$. yr BP at the base of the sediment record.

The series of four AMS dates indicates a consistent sedimentation rate (Figure 3). The average sediment accumulation rate for the entire core is $0.41 \mathrm{~mm} / \mathrm{yr}$. In detail it is $0.52 \mathrm{~mm} / \mathrm{yr}$ (recent $-1770 \mathrm{cal}$. yr BP), $0.53 \mathrm{~mm} / \mathrm{yr}$ (1770-5170 cal. yr BP), $0.34 \mathrm{~mm} / \mathrm{yr}$ (5170-7620 cal. yr BP) and $0.32 \mathrm{~mm} / \mathrm{yr}(7620-11,700$ cal. yr BP) (see Figure 6).

\section{Description of the pollen diagram}

The total number of identified different pollen and spore types is 108. The pollen diagram (Figure 4) shows records of the most abundant pollen and spore taxa. Figure 5 illustrates records of the ecological groups, the pollen sum, the pollen concentration, and the pollen and charcoal influx. A cluster analysis of terrestrial pollen taxa produces a dendrogram that permits zonation of the record into the zones RV-1, RV-2 and RV-3 (Figure 5).

\section{Zone RV-1 (490-405 cm; c. 11,700-8990 cal. yr BP)}

This zone is marked by a stable representation of lower mountain rainforest (LMF) and upper mountain rainforest (UMF) pollen taxa such as Weinmannia (8-12\%), Hedyosmum (5-10\%) and Moraceae/Urticaceae (3-8\%). Subparamo taxa is slightly less than in other zones, Melastomataceae (5-10\%) and Asteraceae (3-8\%) percentages are low. Paramo pollen are well represented, especially Poaceae (30-40\%). Cyperaceae, Liliaceae, Valeriana and Thalictrum (all 1-5\%) percentages are low. Fern spore (12-25\%) percentages are highest in this zone, especially Huperzia (2-8\%). Pollen concentrations (150 000-320000 grains $\left./ \mathrm{cm}^{3}\right)$ are stable.

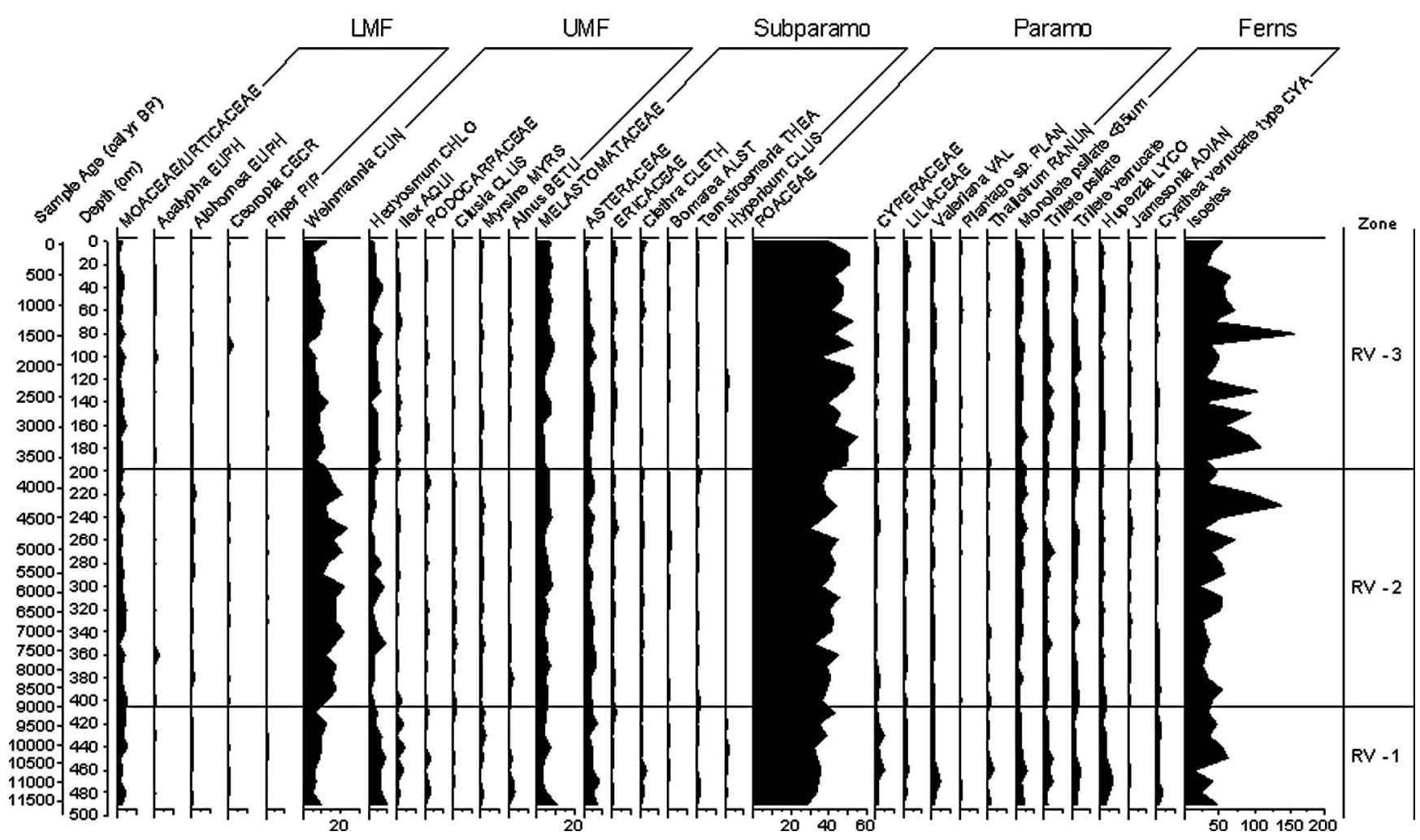

Figure 4 Pollen percentage diagram of the Laguna Rabadilla de Vaca record, showing selected pollen and spore taxa grouped into lower mountain rainforest (LMF), upper mountain rainforest (UMF), subparamo and paramo 


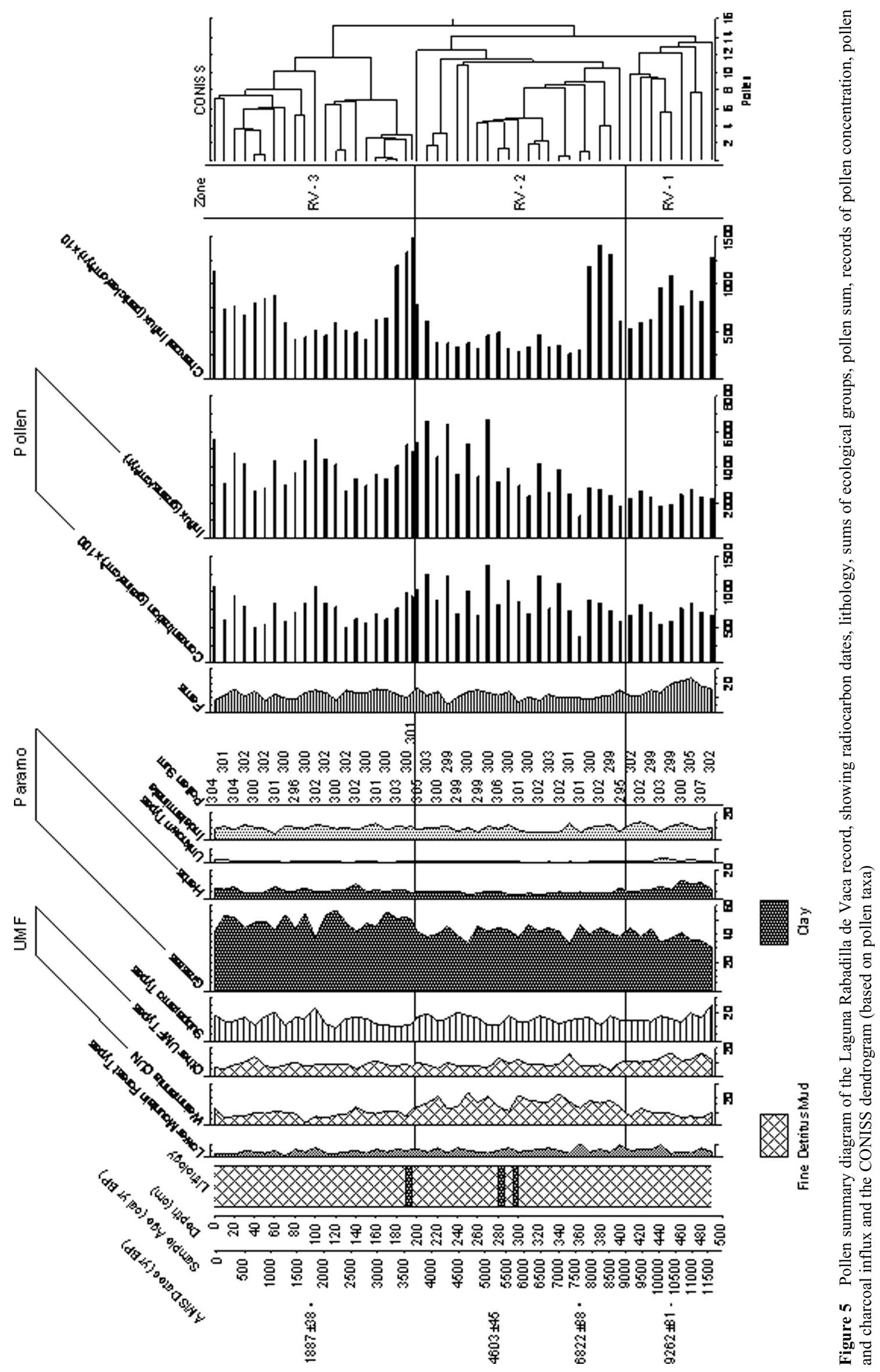




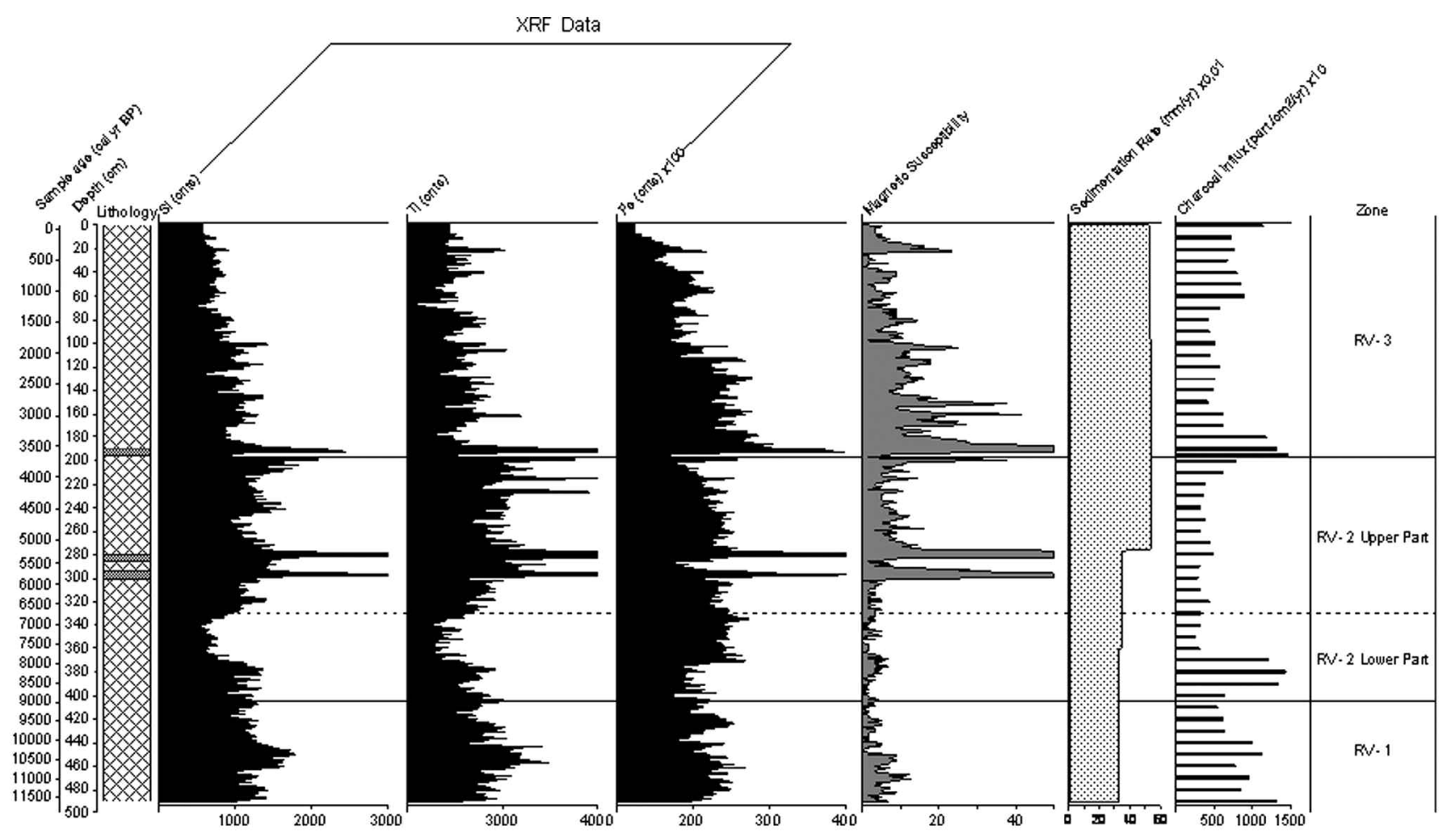

Figure 6 XRF-data, physical properties and charcoal influx for Laguna Rabadilla de Vaca

Pollen influx (6000-8000 grains $/ \mathrm{cm}^{2}$ per yr) is low and charcoal influx (6000-13,000 particles $/ \mathrm{cm}^{2}$ per yr) is high with a decreasing trend, in this zone.

\section{Zone RV-2 (405-197.5 cm; c. 8990-3680 cal. yr BP)}

This zone is marked by low percentages of LMF pollen (eg, Moraceae/Urticaceae; 3-8\%). UMF pollen reach their highest percentages in this zone, especially Weinmannia (12-25\%). Hedyosmum (3-10\%) is low in abundance. Subparamo taxa such as Melastomataceae (5-8\%) and Asteraceae (3-8\%) percentages are stable. Paramo pollen are well represented, especially Poaceae (35-45\%). Cyperaceae, Liliaceae and Valeriana (all 1-3\%) percentages are low. Fern spore (8-15\%) percentages are lower than in previous zone. Pollen concentrations $\left(120000-420000\right.$ grains $\left./ \mathrm{cm}^{3}\right)$ are high. Pollen influx (5000-20,000 grains $/ \mathrm{cm}^{2}$ per yr) is high with an increasing trend throughout this period. Charcoal influx (3000-14000 particles $/ \mathrm{cm}^{2}$ per yr) is high, peaking between 395 and $365 \mathrm{~cm}$.

\section{Zone RV-3 (197.5-0 cm; c. 3680-0 cal. yr BP)}

This zone is marked by low percentages of LMF pollen (eg, Moraceae/Urticaceae; $1-5 \%$ ). UMF pollen such as Weinmannia (4-12\%) and Hedyosmum (3-8\%) decrease compared with the previous zone. Subparamo taxa such as Melastomataceae (5-10\%) and Asteraceae (1-8\%) are stable. Paramo pollen types peak in this zone, especially Poaceae (40-55\%). Liliaceae and Valeriana (both 1-3\%) percentages are low. Fern spore percentages $(8-15 \%)$ are stable. Pollen concentrations $\left(180000-260000\right.$ grains $\left./ \mathrm{cm}^{3}\right)$ are lowest in this zone. Pollen influx (8000-16000 grains $/ \mathrm{cm}^{2}$ per yr) is high. Charcoal influx (4000-14 000 particles $/ \mathrm{cm}^{2}$ per yr) is high with peaks at the beginning of this period.

\section{XRF-scanning and physical properties}

The main zonation of the pollen diagram (RV-1, RV-2 and RV-3) is also used for XRF data. Zone RV-2 is subdivided into a lower part (405-330 cm, 8990-6380 cal. yr BP) and an upper part (330-197.5 cm, 6380-3680 cal. yr BP) (Figure 6). The high peaks at 190, 280 and $295 \mathrm{~cm}$ core depth occur at the same depth as the thick clay layers.

A correlation matrix (Spearman Rank Order Correlation) showed positive correlations of $\mathrm{Ti}$ to $\mathrm{K}$ and $\mathrm{Si}(r=0.863$ and $0.809, \mathrm{~K}$ to Si $r=0,817, p<0.001)$. Al was also correlated significantly to all three elements (Si: $r=0.723, \mathrm{~K}: r=0.675$, Ti: $r=0.633, p>0.001)$ as well as $\mathrm{Ca}(\mathrm{K}: r=0.583$, Si: $r=0.579$, Al: $r=0.539$, Ti: $r=0.501, p<0.001)$. As correlations among the mentioned elements are significant and show high correlation coefficients. Only $\mathrm{Ti}$ and $\mathrm{Si}$ are plotted for palaeoenvironmental reconstruction. Fe showed little correlation to these elements (Al: $r=0.149$, Ti: $r=0.160$, Si: $r=0.226, \mathrm{~K}: r=$ $0.240, p<0.001)$. All other element concentrations were too low for accurate interpretation. In zone RV-1 Ti and Si counts reach their highest concentrations with a maximum between 465 and $440 \mathrm{~cm}$. In contrast, in the lower part of zone RV-2 Ti and $\mathrm{Si}$ values are low. The transition between zone RV-2 and zone RV-1 is characterized by high concentrations of Ti and $\mathrm{Si}$, with maxima at 295, 280 and $190 \mathrm{~cm}$ before a sharp decrease to the lowest values of the record in zone RV-3.

Magnetic susceptibility ( $\kappa)$ shows only moderate correlation to the elements mentioned above (Ti: $r=0.44, p=0.006, \mathrm{~K}: r=$ 0.468, $p=0.003$, Si: $r=0.422, p=0.009, \mathrm{Ca}: r=-0.28, p=0.088$ and Fe: $r=0.215, p=0.194$ ), but generally follows the peaks of the elements it is best correlated with, especially at the depths of the clay layers. 


\section{Interpretation and discussion}

The pollen record from Laguna Rabadilla de Vaca (3312 m) indicates that paramo vegetation has surrounded the lake throughout the Holocene. The bottom of the sediment core shows an extrapolated age of c. $11700 \mathrm{cal}$. yr BP. As it was impossible to recover deeper sediments, we conclude that material was too coarse for recovery and might reflect the deglaciation of the basin. During last glacial maximum (LGM), the maximum equilibrium line of the glaciers is estimated at $c .3100 \mathrm{~m}$ for the Podocarpus National Park region, with glaciers terminating at elevations of c. 2750-2800 m (Rozsypal, 2000). After Clapperton (1987), a moraine low stand is described at $2800 \mathrm{~m}$ for the Las Cajas National Park (Figure 1) in western central Ecuador. At the El Tiro-Pass (2810 m, Figure 1), c. $30 \mathrm{~km}$ north of the core site, the bottom of the sediment core shows an age of c. $20100 \mathrm{cal}$. yr BP, indicating early deglaciation or lack of glaciation (Niemann and Behling, 2008a). At Laguna Chochos (3285 m, Figure 1), eastern Peruvian Andes, deglaciation was locally completed at c. $11700 \mathrm{cal}$. yr BP (Bush et al., 2005).

\section{The early-Holocene period}

During the early-Holocene period (RV-1, c. 11 700-8990 cal. yr BP) herb-paramo was the main vegetation type around Laguna Rabadilla de Vaca. The herb-paramo, associated with a high number of ferns, mainly Huperzia, was rich in Poaceae, Cyperaceae, Valeriana and Liliaceae, reflecting cool and relatively wet climatic conditions. A slow warming during this period is indicated by the pollen record from El Tiro-Pass (2810 m, Figure 1), which shows a slight expansion of subparamo and upper mountain rainforest vegetation into higher elevations during the early Holocene. Fern spores including tree ferns (Cyathea) expanded markedly, reflecting a change to more humid conditions (Niemann and Behling, 2008a). The pollen record from Laguna Cocha Caranga (2710 m, Figure 1), c. $25 \mathrm{~km}$ north of the core site, shows an increase of upper mountain forest taxa, mainly Weinmannia, during the latePleistocene to early-Holocene period (c. 14 500-9700 cal. yr BP), reflecting an increase in temperature and a shift of vegetation zones, as well as the treeline to higher elevations (Niemann and Behling, 2008b).

In contrast, at Laguna Chochos (3285 m, Figure 1), an already warm and wet early Holocene (c. 11 500-9500 cal. yr BP) was estimated (Bush et al., 2005). Fossil pollen data from Laguna Tuctua in the central Peruvian Andes (4000 m, Figure 1) point to increasing moisture, as well as higher temperatures from about 12910 to 7850 cal. yr BP (Hansen et al., 1994).

High Ti values are commonly regarded as an indicator for detrital input (Haberzettl et al., 2005, 2006, 2007, 2008; Mayr et al., 2005; Haberzettl, 2006) and confirm the assumption of wet conditions during RV-1. This immobile element probably was delivered to the lake via fluvial processes resulting in enhanced Ti input during wetter, and reduced $\mathrm{Ti}$ input during drier, conditions (eg, Haberzettl et al., 2005, 2007). Hence, Ti likely reflects hydrological variations in that area. However, input of Ti during RV-1 might also have been caused by more open vegetation cover relative to modern times, as it is also reflected by low pollen influx during this time. Probably both factors (increased humidity and erosivity) caused the high Ti values during the early Holocene period in the earliest part of the record, which are almost synchronous with the maximum herb and fern percentages.

The Fe record, which was also interpreted as an indicator for fluvial terrigenuous sediment influx in other studies (eg, Richter et al., 2006) cannot be applied as climate proxy at Laguna Rabadilla de Vaca. While Fe and Ti are closely related in the terrigenuous fraction, reduced $\mathrm{Fe}$ is prone to diagenetic remobilization whereas $\mathrm{Ti}$ is inert to diagenetic processes (Granina et al., 2004; Richter et al.,
2006) which probably explains the different patterns of $\mathrm{Ti}$ and $\mathrm{Fe}$ at Laguna Rabadilla de Vaca. However, the signal of clastic input of Fe can at least be traced at the depths of the clay layers. Though the correlation coefficient between $\mathrm{Fe}$ and $\kappa$ is rather low the same seems to be the case for $\kappa$ as reductive dissolution of ferric iron components also has a strong impact on the rock magnetic properties of the sediment (Kasten et al., 2003) and rock-magnetic parameters are not palaeoclimate proxies per se (Geiss et al., 2003). $\kappa$ can only be used as an indicator for detrital input at obvious parts of the record, ie, at the depths of the clay layers.

\section{The middle-Holocene period}

The middle-Holocene period (RV-2, c. 8990-3680 cal. yr BP) at Laguna Rabadilla de Vaca is characterized by an increase of Weinmannia, reflecting a shift of vegetation zones, as well as the treeline into higher elevations. Weinmannia has a large altitudinal range in the Podocarpus National Park region, occurring from lower mountain rainforest up to paramo vegetation zone (Lozano et al., 2003; Homeier and Werner, 2005). Table 2 shows the number of Weinmannia species, found in different vegetation zones. The highest numbers of Weinmannia species are found in the upper mountain rainforest vegetation zone.

Today, the slopes above Laguna Rabadilla de Vaca are covered with shrub-paramo vegetation, while herb-paramo vegetation occurs on the flat areas near the lake (Figure 2). It might be possible that the shrub-paramo vegetation spread around the whole lake during this period.

Consequently the strong increase of Weinmannia indicates warmer climatic conditions between c. 8990 and 3680 cal. yr BP, corresponding to the worldwide Holocene thermal optimum which is also visible in various regional archives. For example from c. 8900 to 3300 cal. $\mathrm{yr}$ BP an upper mountain rainforest developed at the El Tiro-Pass (2810 m, Figure 1), where nowadays subparamo vegetation occurs, suggesting a warmer climate than present, as well as a shift of the treeline to higher elevations (Niemann and Behling, 2008a). Ice cores from Huascaran (c. $6050 \mathrm{~m}$, Figure 1) in the central Peruvian Andes show that the climate was warmest from c. 9455 to 5960 cal. yr BP (Thompson et al., 1995). At Lake Titicaca (3810 m, Figure 1), central Peruvian Andes, a dry event between c. 9000 and 3100 cal. yr BP is inferred from changes in the vegetation composition (Paduano et al., 2003), in combination with a well-documented early- to middle-Holocene lowstand, between $c .8000$ and 3600 cal. yr BP (D'Agostino et al., 2002). Pollen, charcoal and radiocarbon data from the Colombian inter-Andean Cauca Valley (1020 m, Figure 1), indicates drier climatic conditions than present from c. 9670 to 3030 cal. yr BP (Berrio et al., 2002).

The Holocene climate development of Laguna Rabadilla de Vaca generally corresponds to the previous studies of the Podocarpus National Park region, as well as to other palaeoenvironmental records of tropical South America (discussed above). Additionally, our data also correspond to studies from outside tropical South America (Haug et al., 2001; Kim et al., 2002; Li et al., 2002; Andersen et al., 2004; Liew et al., 2006).

Low $\mathrm{Ti}$ values suggest dry climatic conditions at Laguna Rabadilla de Vaca for the early middle Holocene (c. 8990-6380 cal. yr BP). At Laguna Cocha Caranga (2710 m, Figure 1) drier climatic conditions occurred from c. 9700 to $6900 \mathrm{cal}$. yr BP, characterized by high percentages of Cyperaceae and Isoetes coupled with low concentration of Botryococcus, reflecting a lower lake level and an enlarging of marshy lake shores, because of reduced precipitation (Niemann and Behling, 2008b). At Laguna Chochos (3285 m, Figure 1) a warm and wet early Holocene was interrupted by a warm-dry event that lasted from $c .9500$ to $7300 \mathrm{cal}$. yr BP (Bush et al., 2005). The pollen record Yasuni National Park (220 m, Figure 1), Ecuadorian Amazonia, shows a long-lasting plateau of Cecropia pollen (c. $8700-5800$ cal. yr BP) which is tentatively 
Table 2 Altitudinal range of different Weinmannia species for the Podocarpus National park region

\begin{tabular}{lcc}
\hline & Lozano et al. (2003) & Homeier and Werner (2005) \\
\hline LMF & 2 species & 5 species \\
UMF & 7 species & 4 species \\
Subparamo & 5 species & 2 species \\
Paramo & $\mathrm{x}$ & $\mathrm{x}$ \\
Shrub-paramo & $4-5$ species & $\mathrm{x}$ \\
Herb-paramo & 2 species & $\mathrm{x}$ \\
\hline
\end{tabular}

$\mathrm{x}$, no data available

interpreted to a period of increased tree mortality, indicating a drought period (Weng et al., 2002). In contrast, the pollen record from Laguna Loma Linda (310 m, Figure 1), Colombian savannah, shows lower annual and stronger seasonal precipitation signals than today during the period from $c$. 9650 to $6850 \mathrm{cal}$. yr BP (Behling and Hooghiemstra, 2000).

High $\mathrm{Ti}$ values suggest wetter climatic conditions for the late middle Holocene (c. 6380-3680 cal. yr BP). Accordingly, at Laguna Cocha Caranga (2710 m, Figure 1) wetter climatic conditions occurred from c. 6900 to 4200 cal. yr BP. Low percentages of Cyperaceae and Isoetes coupled with high concentration of Botryococcus reflect an enlarging of the water body. Marshy lake shores were flooded at that time, because of higher precipitation (Niemann and Behling, 2008b). Maximum Holocene lake level at Lake Aricota (2800 m, Figure 1), central Peruvian Andes, was attained before $c .7000$ cal. yr BP and ended c. 2800 cal. yr BP (Placzek and Quade, 2001). The pollen record from Laguna Loma Linda (310 m, Figure 1) shows that during the period from c. 6850 to $3900 \mathrm{cal}$. yr BP rainforest taxa increased markedly, reflecting an increase in precipitation (Behling and Hooghiemstra, 2000). The pollen record from Yasuni National Park (220 m, Figure 1) also indicates wet climatic conditions from c. 5800 to $4900 \mathrm{cal}$. yr BP (Weng et al., 2002).

Landslides on the slopes above Laguna Rabadilla de Vaca, contemporaneous with the peaks in $\mathrm{Ti}$, and probably caused by strong precipitation events, may be responsible for the thick clay layers at 190, 280 and $295 \mathrm{~cm}$ sediment depth (between 5800 and $3600 \mathrm{cal}$. yr BP), consistent with an increase in humidity. This may also explain the increase in sedimentation rate from 0.34 to $0.52 \mathrm{~mm} / \mathrm{yr}$. The clay layer at $280 \mathrm{~cm}$ was counted for pollen and spores. The high occurrence of shrub pollen, c. 75\%, especially Weinmannia (30\%), Hedyosmum and Melastomataceae (both 8-10\%), low values of Poaceae (10\%) and ferns (2\%), as well as the absence of Isoetes point to the slopes as the source of this sediment. The clay layers display sharp erosive bases, suggesting rapid sedimentation events.

\section{The late-Holocene period}

From the beginning of the late-Holocene period (RV-3, c. $3680 \mathrm{cal}$. yr BP to present) a Poaceae-dominated (40-55\%) herb-paramo expanded at Laguna Rabadilla de Vaca, reflecting cooler climatic conditions relative to the middle-Holocene period. A decrease of $\mathrm{Si}$ and Ti points to less erosion, probably resulting from drier climatic conditions throughout the late Holocene. This is also consistent with the record from El Tiro-Pass ( $2810 \mathrm{~m}$, Figure 1) where modern subparamo vegetation became established after $3300 \mathrm{cal}$. yr BP, indicating a shift of vegetation zones into lower elevation, because of cooler climatic conditions during the late-Holocene period (Niemann and Behling, 2008a). At Laguna Cocha Caranga (2710 $\mathrm{m}$, Figure 1) drier climatic conditions occurred from c. 4200 to 1300 cal. yr BP. Percentages of fern spores decrease, low concentration of Botryococcus coupled with a strong increase of Cyperaceae indicates a lake level low stand, owing to a reduction in precipitation. The water body shrank, and marshy lake shores developed. From c. 1300 cal. yr BP to the present, a peat bog became established, reflecting wetter conditions during this period (Niemann and Behling, 2008b). At the Cariaco Basin, a trend toward drier conditions is evident from $c .5400$ cal. yr BP to present, with a precipitation minimum during the time interval from c. 3800 to $2800 \mathrm{cal}$. yr BP (Haug et al., 2001).

In contrast, a moist late Holocene is described elsewhere. The pollen record from Laguna Loma Linda (310 m, Figure 1) shows a continued increase of rainforest taxa from c. 3900 to $2300 \mathrm{cal}$. yr BP, precipitation was still increasing and the length of the annual dry period possibly shortened. From c. 2300 cal. yr BP onwards, grass savannah expanded, likely as a result of increased human impact on the vegetation (Behling and Hooghiemstra, 2000). The pollen record of the Yasuni National Park (220 m, Figure 1) shows wet climatic conditions from c. 3700-1000 cal. yr BP and dry climatic conditions from c. $1000 \mathrm{cal}$. yr BP to present (Weng et al., 2002).

The very high charcoal influx at the beginning of this zone may suggest human activities by uncontrolled burning near Laguna Rabadilla de Vaca. The high number of Poaceae may be a result of these burning activities in conjunction with the cooler and drier climatic conditions. At Laguna Cocha Caranga (2710 m, Figure 1) Myrica strongly expands from c. $4800 \mathrm{cal}$. yr BP which may also indicate settlement in the Loja region. The first known human activity in the region of Loja (Figure 1), indicated by ceramic fragments, has been dated around $4000 \mathrm{cal}$. yr BP. Since then the native Palta culture established around Loja (Guffroy, 2004).

\section{Conclusions}

During the early Holocene (11 700-8990 cal. yr BP) climatic conditions were cool and relatively wet. Herb-paramo was the main vegetation type at the Laguna Rabadilla de Vaca. The herb-paramo, associated with a high number of ferns, mainly Huperzia, was rich in Poaceae, Cyperaceae, Valeriana and Liliaceae. The middle Holocene (8990-3680 cal. yr BP) is characterized by warmer climatic conditions than modern times (Holocene thermal optimum). Drier climatic conditions for the early middle Holocene (8990-6380 cal. yr BP) and wetter climatic conditions for the late middle Holocene (6380-3680 cal. yr BP) are inferred. A strong increase of Weinmannia reflects a shift of vegetation zones into higher elevation and/or a spread of a shrub-paramo vegetation type around the whole lake. Cooler and drier climatic conditions relative to the late middle-Holocene period become established since the beginning of the late Holocene (3680 cal. yr BP). A Poaceae-dominated $(40-55 \%)$ herb-paramo expanded until modern times.

The data from Laguna Rabadilla de Vaca reflect Holocene climate and vegetation development that is consistent in comparison with preceding studies from the Podocarpus National Park region. The Holocene thermal optimum assumed in this study fits well with the interregional climate development.

\section{Acknowledgements}

Felix Matt (research station leader) is thanked for his logistical support and for his information about the study region. We also thank Jürgen Homeier for providing his species lists and his collected flower samples and Achim Bräuning, Henrik Stark and Markus Hofmann for accompanying us on the 3-day field trip from Vilcabamba to Laguna Rabadilla de Vaca. Thanks to the University of Bremen for use of the XRF- and MS-scanner. The project FOR 402/D1 (Vegetation-, climate- and fire dynamics in 
the Podocarpus National Park region) is kindly funded by the Deutsche Forschungsgemeinschaft (DFG).

\section{References}

Andersen, C., Koc, N. and Moros, M. 2004: A highly unstable Holocene climate in the subpolar North Atlantic: evidence from diatoms. Quaternary Science Reviews 23, 2155-66.

Bader, M.Y. 2007: Tropical alpine treelines; how ecological processes control vegetation patterning and dynamics. PhD Thesis, Wageningen University.

Barthlott, W., Mutke, J., Rafiqpoor, M.D., Kier, G. and Kreft, H 2005: Global centres of vascular plant diversity. Nova Acta Leopoldina 92, 61-83.

Beck, E., Bendix, J., Kottke, I., Makeschin, F. and Mosandl, R. 2008: Gradients in a tropical mountain ecosystem of Ecuador. Ecological Studies 198, Springer Verlag.

Behling, H. 1993: Untersuchungen zur spätpleistozänen und holozänen Vegetations- und Klimageschichte der tropischen Küstenwälder und der Araukarienwälder in Santa Catarina (Südbrasilien). Dissertationes Botanicae 206, J. Cramer.

Behling, H. and Hooghiemstra, H. 2000: Holocene Amazon rain forest - savanna dynamics and climatic implications: high resolution pollen record Laguna Loma Linda in eastern Colombia. Journal of Quaternary Science 15, 687-95.

Bendix, J., Rollenbeck, R. and Palacios, W.E. 2004: Cloud detection in the Tropics - a suitable tool for climate-ecological studies in the high mountains of Ecuador. International Journal of Remote Sensing $25,4521-50$.

Berrio, J.C., Hooghiemstra, H., Marchant, R. and Rangel, O. 2002: Late-glacial and Holocene history of the dry forest area in the south Colombian Cauca Valley. Journal of Quaternary Science 17, 667-82. Bosman, A.F., Hooghiemstra, H. and Cleef, A.M. 1994: Holocene mire development and climatic change from a high Andean Plantago rigida cushion mire. The Holocene 43, 233-43.

Bush, M.B., Hansen, B.C.S., Rodbell, D.T., Seltzer, G.O., Young, K.R., Leon, B., Abbott, M.B., Silman, M.R. and Gosling, W.D. 2005: A 17 000-year history of Andean climate and vegetation change from Laguna de Chochos, Peru. Journal of Quaternary Science 20, 703-14. Bussmann, R.W. 2001: The montane forests of Reserva Biologica San Francisco (Zamora-Chinchipe, Ecuador). Vegetation zonation and natural regeneration. Erde 132, 9-25.

2005: Bosques andinos del sur de Ecuador, clasificación, regeneración y uso. Review of Peruvian Biology 12, 203-16.

Clapperton, C.M. 1987: Glacial geomorphology, Quaternary glacial sequence and palaeoclimatic inferences in the Ecuadorian Andes. In Gardiner, V., editor, International geomorphology 1986 part II. Wiley, $843-70$.

D’Agostino, K., Seltzer, G., Baker, P., Fritz, S. and Dunbar, R. 2002: Late-Quaternary lowstands of Lake Titicaca: evidence from high-resolution seismic data. Palaeogeography, Palaeoclimatology, Palaeoecology 179, 97-111.

Emck, P. 2007: A climatology of south Ecuador - with special focus on the major Andean ridge as Atlantic-Pacific climate divide. Dissertation, Universität Erlangen-Nürnberg.

Faegri, K. and Iversen, J. 1989: Textbook of pollen analysis. John Wiley and Sons.

Mayr, C., Fey, M., Haberzettl, T., Janssen, S., Lücke, A., Maidana, N., Ohlendorf, C., Schäbitz, F., Schleser, G.H., Struck, U., Wille, M. and Zolitschka, B. 2005: Palaeoenvironmental changes in southern Patagonia during the last millennium recorded in lake sediments from Laguna Azul (Argentina). Palaeogeography, Palaeoclimatology, Palaeoecology 228, 203-227.

Geiss, C.E., Umbanhowar, C.E., Camill, P. and Banerjee, S.K. 2003: Sediment magnetic properties reveal Holocene climate change along the Minnesota prairie-forest ecotone. Journal of Paleolimnology $30,151-66$.

Granina, L., Müller, B. and Wehrli, B. 2004: Origin and dynamics of Fe and Mn sedimentary layers in Lake Baikal. Chemical Geology 205, 55-72. Grimm, E.C. 1987: CONISS: a Fortran 77 program for stratigraphically constrained cluster analysis by the method of the incremental sum of squares. Computer and Geosciences 13, 13-35.
Guffroy, J. 2004: Catamayo precolombino. Investigaciones arqueologicas en la provincia de Loja (Ecuador). IRD editions.

Haberzettl, T. 2006: Late Quaternary hydrological variability in southeastern Patagonia-45,000 years of terrestrial evidence from Laguna Potrok Aike. PhD Thesis, Institute of Geography, University of Bremen, http://nbn-resolving.de/urn:nbn:de:gbv:46diss000103918, $142 \mathrm{pp}$

Haberzettl, T., Fey, M., Lücke, A., Maidana, N., Mayr, C., Ohlendorf, C., Schäbitz, F., Schleser, G.H., Wille, M. and Zolitschka, B. 2005: Climatically induced lake level changes during the last two millennia as reflected in sediments of Laguna Potrok Aike, southern Patagonia (Santa Cruz, Argentina). Journal of Paleolimnology 33, 283-302.

Haberzettl, T., Wille, M., Fey, M., Janssen, S., Lücke, A., Mayr, C. Ohlendorf, C., Schäbitz, F., Schleser, G. and Zolitschka, B. 2006: Environmental change and fire history of southern Patagonia (Argentina) during the last five centuries. Quaternary International $158,72-82$.

Haberzettl, T., Corbella, H., Fey, M., Janssen, S., Lücke, A., Mayr, C., Ohlendorf, C., Schäbitz, F., Schleser, G., Wille, M., Wulf, S. and Zolitschka, B. 2007: Lateglacial and Holocene wet-dry cycles in southern Patagonia: chronology, sedimentology and geochemistry of a lacustrine record from Laguna Potrok Aike, Argentina. The Holocene $17,297-310$.

Haberzettl, T., Kück, B., Wulf, S., Anselmetti, F., Ariztegui, D., Fey, M., Janssen, S., Lücke, A., Mayr, C., Ohlendorf, C., Schäbitz, F., Schleser, G., Wille, M. and Zolitschka, B. 2008: Hydrological variability in southeastern Patagonia and explosive volcanic activity in the southern Andean Cordillera during Oxygen Isotope Stage 3 and the Holocene inferred from lake sediments of Laguna Potrok Aike, Argentina. Palaeogeography, Palaeoclimatology, Palaeoecology 259, 213-29.

Hansen, B.C.S., Seltzer, G.O. and Wright, H.E. 1994: Late Quaternary vegetation change in the central Peruvian Andes. Palaeogeography, Palaeoclimatology, Palaeoecology 109, 263-85.

Haug, G.H., Hughen, K.A., Peterson, L.C., Sigman, D.M. and Röhl, U. 2001: Southward migration of the intertropical convergence zone through the Holocene. Science 293, 1304-308.

Homeier, J. and Werner, F.A. 2005: Preliminary checklist of the Spermatophytes of the Reserva San Francisco (Province ZamoraChinchipe, Ecuador). Department of Plant Ecology, Albrecht-vonHaller-Institute for Plant Sciences, University of Göttingen.

Hooghiemstra, H. 1984: Vegetation and climatic history of the High Plain of Bogota, Colombia: a continuous record of the last 3,5 million years. Dissertationes Botanicae 79, Cramer, 368 pp.

Kasten, S., Zabel, M., Heuer, V. and Hensen, C. 2003: Processes and signals of nonsteady-state diagenesis in deep-sea sediments and their pore waters. In Wefer, G., Mulitza, S. and Ratmeyer, V., editors, The South Atlantic in the Late Quaternary: reconstruction of material budget and current systems. Springer, 431-59.

Kim, J.-H., Schneider, R.R., Müller, P.J. and Wefer, G. 2002: Interhemispheric comparison of deglacial sea-surface temperature patterns in Atlantic eastern boundary currents. Earth and Planetary Science Letters 194, 383-93.

Li, S.-H., Sun, J.-M. and Zhao, H. 2002: Optical dating of dune sands in the northeastern deserts of China. Palaeogeography, Palaeoclimatology, Palaeoecology 181, 419-29.

Liew, P.M., Lee, C.Y. and Kuo, C.M. 2006: Holocene thermal optimal and climate variability of East Asian monsoon inferred from forest reconstruction of a subalpine pollen sequence, Taiwan. Earth and Planetary Science Letters 250, 596-605.

Litherland, M., Aspden, J.A. and Jemielita, R.A. 1994: The metamorphic belts of Ecuador. Overseas Memoir of the British Geological Survey 11, 1-147.

Lozano, P., Delgado, T. and Aguirre, Z. 2003: Estado actual de la flora endemica exclusive y su distribucion en el Occidente del Parque Nacional Podocarpus. Funbotanica \& Herbario y Jardin Botanico.

McCormac, F.G., Hogg, A.G., Blackwell, P.G., Buck, C.E., Higham, T.F.G. and Reimer, P.J. 2004: SHCal04 Southern Hemisphere calibration 0-11.0 cal. kyr BP. Radiocarbon 46, 1087-92. Niemann, H. and Behling, H. 2008a: Late Quaternary vegetation, climate and fire dynamics inferred from the El Tiro record in the southeastern Ecuadorian Andes. Journal of Quaternary Science 23, 203-12. 
2008b: Late Pleistocene and Holocene vegetation development, climate variability and human impact inferred from Cocha Caranga multiproxy records in the southeastern Ecuadorian Andes. Palaeogeography, Palaeoclimatology, Palaeoecology in review.

Paduano, G.M., Bush, M.B., Baker, P.A., Fritz, S.C. and Seltzer, G.O. 2003: A vegetation and fire history of Lake Titicaca since the Last Glacial Maximum. Palaeogeography, Palaeoclimatology, Palaeoecology 194, 259-79.

Placzek, C. and Quade, J. 2001: Holocene lake-level fluctuations of Lake Aricota, southern Peru. Quaternary Research 56, 181-90.

Richter, M. and Moreira-Munoz, A. 2005: Climatic heterogeneity and plant diversity in southern Ecuador experienced by phytoindication. Review of Peruvian Biology 12, 217-38.

Richter, T., Van der Gaast, S., Koster, B., Vaars, A., Gieles, R., De Stigter, H., De Haas, H. and Van Weering, T. 2006: The Avaatech XRF core scanner: technical description and applications to NE Atlantic sediments. In Rothwell, R.G., editor, New techniques in sediment core analysis. Geological Society, London, Special Publications 267, 39-50. Rozsypal, A.A. 2000: Die pleistozäne Glazialmorphologie in Ecuador und Nordperu unter besonderer Betrachtung der Cordillera Oriental bei
Loja. Diplomarbeit, Institut für Geographie, Universität ErlangenNürnberg (unpublished).

Stuiver, M. AND Reimer, P. 1993: EXTENDED 14C DATABASE AND REVISED CALIB RADIOCARBON CALIBRATION PROGRAM. Radiocarbon 35, 215-30.

Thompson, L.G., Mosley-Thompson, E., Davis, M.E., Lin, P.N., Henderson, K.A., Cole-Dai, J., Bolzan, J.F. AND Liu, K.B. 1995: LATE GLACIAL STAGE AND HOLOCENE TROPICAL ICE CORE RECORDS FROM HuASCARAN, PERU. Science 269, 46-50.

Tjallingii, R., Röhl, U., Kölling, M. and Bickert, T. 2007: Influence of the water content on x-ray fluorescence core-scanning measurements in soft marine sediments. Geochemistry, Geophysics, Geosystems 8, Q02004, doi:02010.01029/02006GC001393.

Van der Hammen, T. AND Urrego, C.G. 1978: PREHISTORIC MAN ON THE SABANA DE Bogota: DATA for an ecological prehistory. Palaeogeography, Palaeoclimatology, Palaeoecology 25, 179-90.

Weng, C., Bush, M.B. and Athens, J.S. 2002: Holocene climate change and hydrarch succession in lowland Amazonian Ecuador. Review of Palaeobotany and Palynology 120, 73-90. 